A-rkivoc

Free to Authors and Readers
A Platinum Open Access Journal

for Organic Chemistry
Review

Arkivoc 2021, part ix, 300-314

\title{
Steroidal chalcones and derivatives: A review
}

\author{
Malika Ibrahim-Ouali, ${ }^{* a}$ and Frédéric Dumur ${ }^{b}$ \\ ${ }^{a}$ Aix Marseille Univ, CNRS, Centrale Marseille, iSm2, F-13397 Marseille, France \\ ${ }^{b}$ Aix Marseille Univ, CNRS, ICR, UMR 7273, F-13397 Marseille, France \\ Email: malika.ibrahim@univ-amu.fr
}

Received 08-15-2021

Accepted 10-05-2021

Published on line 12-22-2021

\section{Abstract}

It was observed that the presence of heterocycles to steroids often leads to a change in their physiological activity and the appearance of new interesting biological precursors. Recent developments in the syntheses of steroidal chalcones and their derivatives are described herein. The biological activities of those steroidal derivatives for which data are available are given. The chalcone moiety shows great promise to allow us to develop novel molecules with characteristic functions.

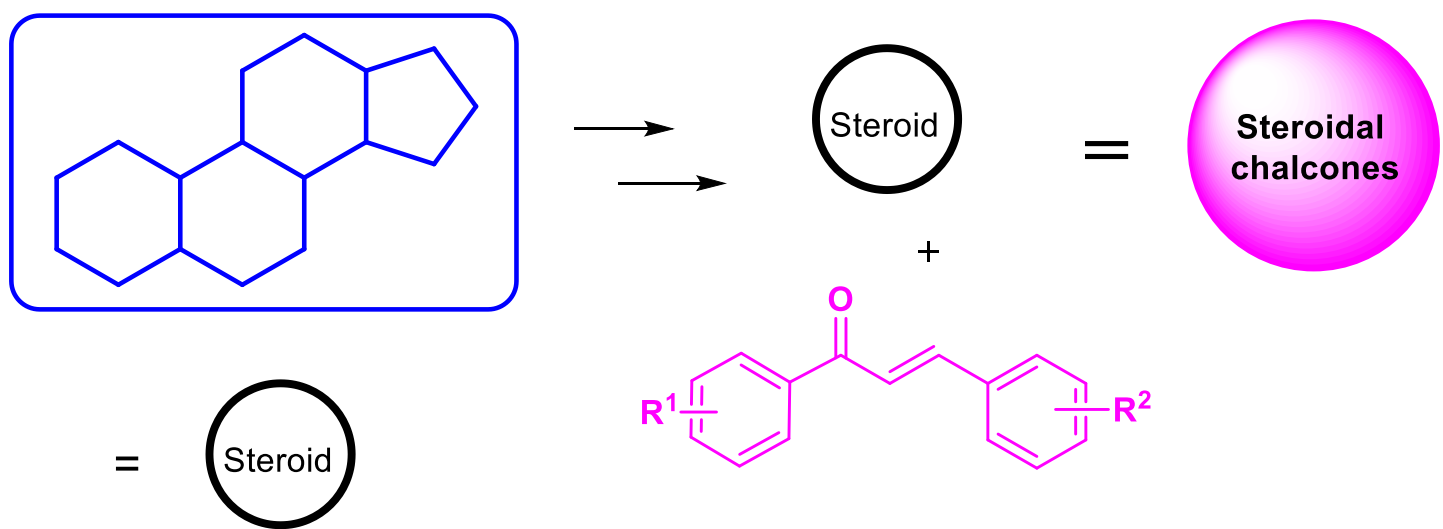

Keywords: chalcones; steroids; enones; pregnenolone. 


\section{Table of Contents}

1. Introduction

2. Synthesis of Steroidal Chalcones and Derivatives

3. Conclusions

4. Acknowledgments

5. References

\section{Introduction}

Steroids represent a large and important class of biologically active polycyclic molecules that are widely used in medicinal chemistry. ${ }^{1-3}$ Even today, the total synthesis of steroids by new and more elaborate strategies continues to interest chemists. Thus, many total syntheses of biologically active steroids have been developed in recent decades. Interest in the total synthesis of such molecules continues to this day. ${ }^{4,5}$

Chalcones (1,3-diphenyl-2-propen-1-one) are well known for their interesting biological properties. It is thus known that chalcones exhibit biological activities, such as anticancer, antioxidant, anti-inflammatory, 6,7 and antimicrobial activities. ${ }^{8,9}$ Two phenyl rings and a ?? ?-unsaturated carbonyl system that connects them constitutes the structural base of chalcone. It has been shown that the nature of the substituents on the phenyl rings and their conformation in the central structure is at the origin of their biological activities. Some work has shown that reactions causing conformational changes, such as substitution on the double bond or epoxidation, can lead to a decrease in bioactivity. ${ }^{10}$

The synthesis of hybrid compounds from the coupling of two or more natural products is at the origin of an inexhaustible new class of molecules with many structures. The objective of such syntheses is to combine the pharmacological properties of two or more biologically active molecules to increase or modulate these activities to obtain derivatives exhibiting new properties. ${ }^{11,12}$ Previous works of literature have been reported that such structures as steroidal chalcones have been shown to bear a lot of different biological activities such as antimicrobial, anti-inflammatory, anticancer, antioxidant, and hypotensive activities. ${ }^{13-16}$

This review presents the various syntheses of steroidal chalcones and their derivatives along with interesting biological activities, which have appeared in the literature in recent years. To the best of our knowledge and much to our surprise, there are no reports on this subject.

\section{Synthesis of Steroidal Chalcones and Derivatives}

In 2007, Negi et al. ${ }^{17}$ reported the synthesis of steroidal chalcones from estradiol. Some of these compounds have significant anticancer activity against certain human cancer cell lines.

Estrone 1 was chosen as the starting aldehyde substrate to carry out the synthesis (Scheme 1).

Thus, to prepare the aldehyde derivative $\mathbf{5}$, a protection reaction by methylation of the phenolic hydroxyl of $\mathbf{1}$ was first carried out using dimethyl sulfate and anhydrous potassium carbonate in anhydrous acetone under reflux. Protected estrone $\mathbf{2}$ was isolated with a yield of 91\%. After a reaction of reduction using sodium borohydride in a mixture of methanol-chloroform (2: 1), the ketone of derivative 2 led to the corresponding alcohol 3 in a yield of $94 \%$ and an acetylation reaction using acetic anhydride in dry pyridine of this latter, 
provided the steroidal derivative 17 -acetate 4 in a very good yield. A Vilsmeier formylation reaction, ${ }^{18}$ using dimethylformamide and phosphorus oxychloride at $80^{\circ} \mathrm{C}$ resulted in the aldehydic substrate 5.

The desired steroidal chalcones deprotected at the C-17 position were obtained by reacting the substrate 5 with various acetophenone derivatives in a solution of hydroalcoholic potassium hydroxide at 7\%. Chalcones 6 and $\mathbf{1 4}$ were then acetylated with acetic anhydride to give the corresponding acetylated derivatives $\mathbf{7}$ and 15.<smiles>O=C1CCC2C3CCc4cc(O)ccc4C3CC[C@H]12</smiles>

1<smiles>COc1ccc2c(c1)CCC1C2CCC2C(=O)CCC21</smiles>

2

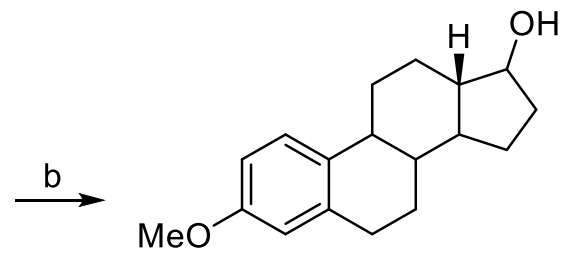

3

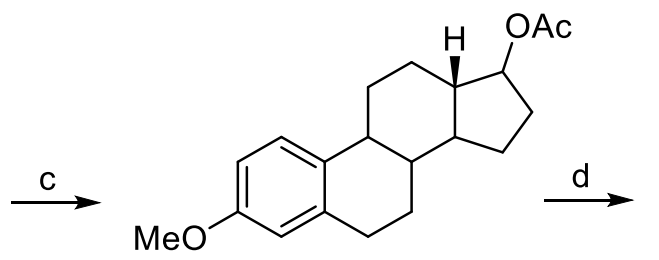

4<smiles>COc1cc2c(cc1C=O)C1CC[C@H]3C(CCCC3OC(C)=O)CCC1C2</smiles>

5<smiles>[R17]OC1CCC2C3CCc4cc(OC)c(/C=C/C([R])=O)cc4C3CC[C@@H]12</smiles>

$\mathbf{R}^{1} \quad \mathbf{R}^{2}$

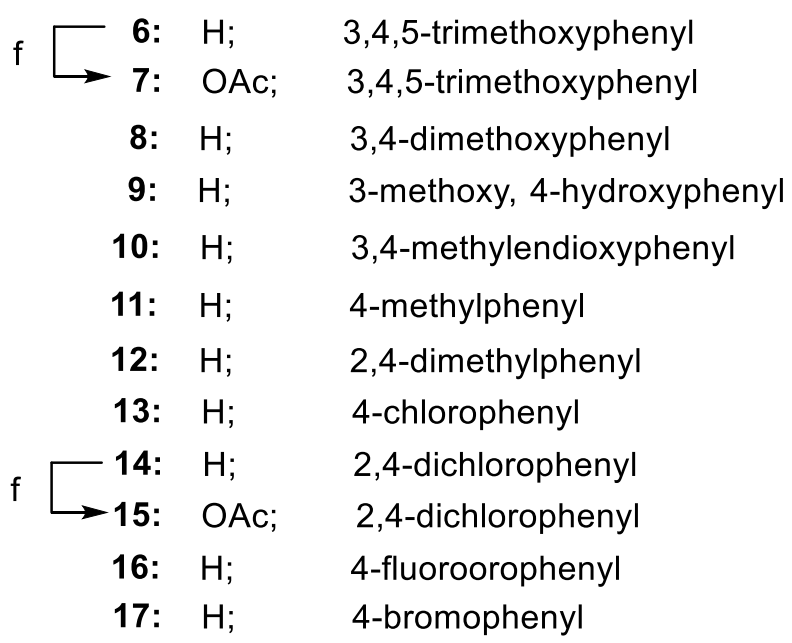

Reagents : a- dimethyl sulfate, $\mathrm{K}_{2} \mathrm{CO}_{3}$, acetone-DCM, reflux, 5h, 91\%; b- $\mathrm{NaBH}_{4}$, $\mathrm{MeOH}-\mathrm{DCM}$, $50{ }^{\circ} \mathrm{C}, 1 \mathrm{~h}, 94 \%$; c- pyridine, acetic anhydride, r.t., $24 \mathrm{~h}, 93 \%$; d- DMF, $\mathrm{POCl}_{3}, 0-10{ }^{\circ} \mathrm{C}$ for $1 \mathrm{~h}$ then heat $80{ }^{\circ} \mathrm{Cfor} 3 \mathrm{~h}, 36 \%$; e- acetophenones as per $\mathrm{R}^{2}, 7 \% \mathrm{KOH}$ solution in $\mathrm{EtOH}$, at $10{ }^{\circ} \mathrm{C}, 24 \mathrm{~h}$, $34-86 \%$; f- substrate, acetic anhydride, pyridine, r.t., $24 \mathrm{~h}$.

Scheme 1. Synthesis of steroidal chalcones 6-17.

One of the chalcone derivatives was further modified to the corresponding 1-indanone derivative 18 using the trifluoroacetic acid-catalyzed Nazarov cyclization reaction (Scheme 2). Indanone $\mathbf{1 8}$ was prepared in a yield of $23 \%$ by treatment in a sealed tube of chalcone 7 with trifluoroacetic acid for 4 h. ${ }^{19}$ 
Some of these chalcones show significant anticancer activity against certain human cancer cell lines. This is the case with derivatives 9 and $\mathbf{1 8}$ which exhibit real activity against MCF-7, a hormone-dependent breast cancer cell line. Indanone 18 showed better activity than the parent chalcone against the MCF-7 breast cancer cell line. Using the erythrocyte as a model system, the most active chalcones were also tested for osmotic hemolysis. It has thus been shown that the fragility of erythrocytes is not modified by these biologically active chalcones. We can therefore consider these chalcones as non-toxic for normal cells.

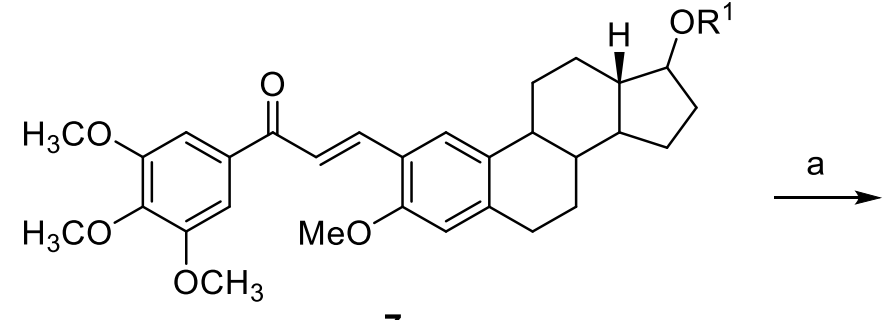

7<smiles>[R17]C1CCC2C3CCc4cc(OC)c(C5CC(=O)c6cc(OC)c(OC)c(OC)c65)cc4C3CC[C@H]12</smiles>

18

Reagents : a- trifluoroacetic acid, sealed tube, $120^{\circ} \mathrm{C}, 4 \mathrm{~h}, 23 \%$.

Scheme 2. Synthesis of the steroidal indanone 18 from chalcone 7.

In 2013, Sarma et al. ${ }^{20}$ reported the synthesis of a new class of chalconoyl pregnenolones based on a ClaisenSchmidt reaction without solvent and under microwave activation conditions.

Cortisone, estrogen, testosterone, and progesterone among others are natural hormones biosynthesized from pregnenolone, a neurosteroid derived from cholesterol by biosynthesis in the adrenal gland and the central nervous system. 21,22

The condensation between the acetate derivative of pregnenolone $\mathbf{2 0}$ and the benzaldehyde $\mathbf{2 1}$ carried out without solvent and by microwave activation using 20 mol\% of the catalyst, $\mathrm{I}_{2}-\mathrm{Al}_{2} \mathrm{O}_{3}$ led to the desired compound with a good yield of $86 \%$ after only $6 \mathrm{~min}$ of reaction at $250 \mathrm{~W}$ of microwave power. The authors were thus able to prepare sixteen new steroidal chalcones by condensation of compound $\mathbf{2 0}$ with different substituted benzaldehydes (Scheme 3). Furthermore, no by-product was observed, these clean reactions led to the desired chalcones with good yields of between 79 and $86 \%$. Longer reaction times or an increase in the percentage of catalysts resulted in the decomposition of the desired product. In addition, the nature of the substituents on the aromatic ring of benzaldehyde does not affect the yield of the desired product. 


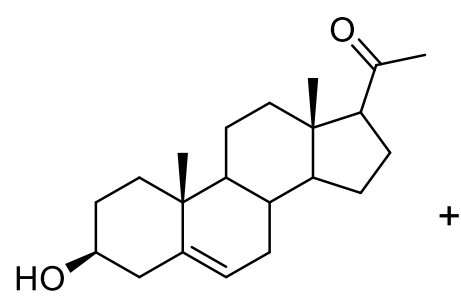

19: $\mathrm{R}=\mathrm{H}$;

20: $R=O A C$

Reagents : $a-\mathrm{I}_{2}-\mathrm{Al}_{2} \mathrm{O}_{3}$, MW, 5-7 min<smiles>O=Cc1ccccc1</smiles>

22-37

(c)<smiles>C=CC(=O)C1CCCCC1</smiles>

$x^{2}$
21

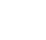


<smiles>CC(=O)c1ccc(O)cc1</smiles>

38<smiles>[R]C=CC(=O)c1ccc(O)cc1</smiles>

39<smiles>[R]C=CC(=O)c1ccc(OCC#C)cc1</smiles>

40a $\mathrm{R}=\mathrm{Ph} ; 95 \%$

40b $\mathrm{R}=p-\mathrm{OMePh} ; 100 \%$

41a $\mathrm{R}=2$-furanyl; $53 \%$

41b $\mathrm{R}=2$-thiofuranyl; $58 \%$

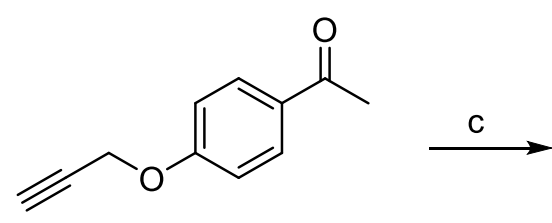

42<smiles>[R]C=CC(=O)c1ccc(OCC#C)cc1</smiles>

40c $\mathrm{R}=p-\mathrm{NMe}_{2} \mathrm{Ph} ; 97 \%$

Reagents :a- R-CHO, NaOH aq., EtOH; b- propargyl bromide, $\mathrm{K}_{2} \mathrm{CO}_{3}$, DMF, r.t. c- $p$-dimethylaminobenzaldehyde, $\mathrm{NaOH}$ aq., EtOH, r.t.

Scheme 4. Synthesis of chalcones derivatives $40 a-c$ and $41 a-b$.

Cholest-5-en-3 $\beta$-ol 43 was activated as bromide in very good yield under Appel conditions, ${ }^{25}$ which means treatment with $\mathrm{CBr}_{4} / \mathrm{PPh}_{3}$ to afford $3 \alpha$-bromocholest-5-ene $\mathbf{4 4}$ due to inversion of the configuration at the $\mathrm{C}-3$ carbon (Scheme 5). An $\mathrm{S}_{\mathrm{N}} 2$ substitution of the bromine atom of compound $\mathbf{4 4}$ with the $\mathrm{N}_{3}$ group was ensured by refluxing with $\mathrm{NaN}_{3}$ in dry DMF to afford $3 \beta$-azidocholest-5-ene $\mathbf{4 5}$ after inversion of the configuration again at the $\mathrm{C}-3$ carbon. The product was isolated in good yield.

The target cholesterol-chalcone conjugates $46 a-c$ and $47 a-b$ were prepared by reacting $3 \beta$-azidocholest-5ene 45 with propargylated chalcones $40 a-c$ and $41 a-b$ under CuAAC conditions. ${ }^{26}$ The reactions proceeded fairly in gently refluxing $\mathrm{THF} / \mathrm{H}_{2} \mathrm{O}$ mixture containing L-ascorbic acid as a reducing agent and a catalytic amount of $\mathrm{CuSO}_{4} \cdot 5 \mathrm{H}_{2} \mathrm{O}$.

The chalcone modified cholesterol derivatives $46 a, c$, and $47 \mathbf{b}$ were active against $E$. coli. They were as active as ampicillin. Thus, the chalcones possessing unsubstituted phenyl, and $p$-dimethylaminophenyl, as well as $2-$ thienyl alternatives were more active than other congeners against $E$. coli. The chalcone derivative 46c emerged as the most promising antimicrobial probe. It was as active as the controls against E. coli, S. aureus, and $C$. albicans. 


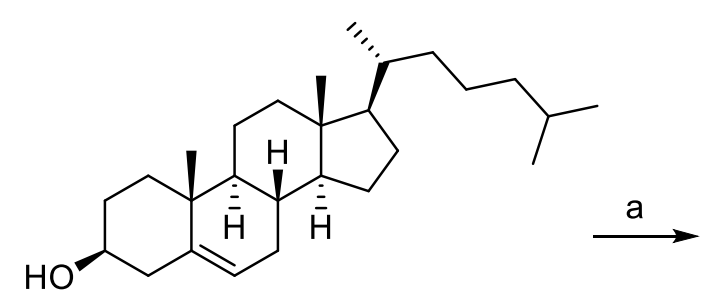

43<smiles>[Y6]CCCC</smiles><smiles>[Y6]CCCC</smiles><smiles>CC(C)CCC[C@H](C)[C@H]1CC[C@H]2[C@@H]3CC=C4C[C@@H](Br)CC[C@]4(C)[C@H]3CC[C@@]21C</smiles>

44

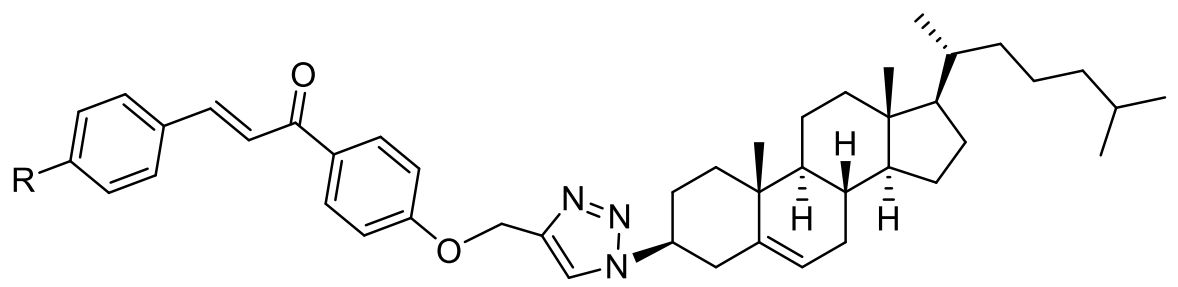

46a-c

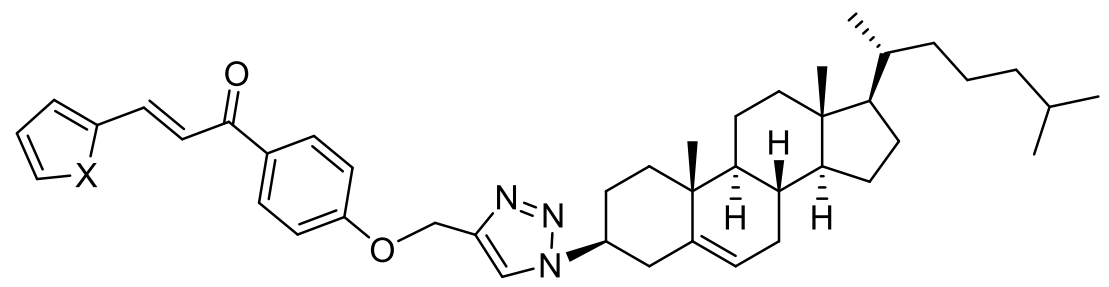

47a-b

Reagents : a- $\mathrm{CBr}_{4}, \mathrm{PPh}_{3}, \mathrm{DCM}(74 \%) ; \mathrm{b}-\mathrm{NaN}_{3}, \mathrm{DMF}, 10{ }^{\circ} \mathrm{C},(63 \%)$; $\mathrm{CuSO}_{4} .5 \mathrm{H}_{2} \mathrm{O}$, L-ascorbic acid (L-AsAc), THF/H $\mathrm{H}_{2} \mathrm{O},(\mathbf{4 6 a}, \mathrm{R}=\mathrm{H}(40 \%)$; 46b, R = OMe (41\%); 46c, R = NMe $2(68 \%) ; 47 a, X=O(47 \%) ; 47 b, X=S(60 \%))$.

Scheme 5. Synthesis of derivatives $46 a-c$ and $47 a-b$. 
In 2016, Liu et al. ${ }^{27}$ described the synthesis of steroidal chalcones using the molecular hybridization approach.

The target molecules can be synthesized from the corresponding alkynes and steroidal azide $\mathbf{4 9}$ through click chemistry. The synthesis of the steroidal azide $\mathbf{4 9}$ is shown in Scheme 6. Bromoacetylation of DHEA under Schotten-Baumann conditions ${ }^{28}$ afforded the corresponding bromide 1 in $87 \%$ yield, which then reacted with $\mathrm{NaN}_{3}$ in DMSO to give the steroidal azide 49 in $85 \%$ yield.

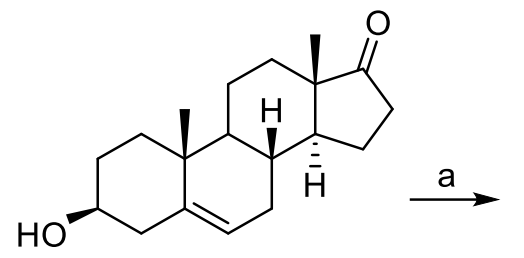

DHEA

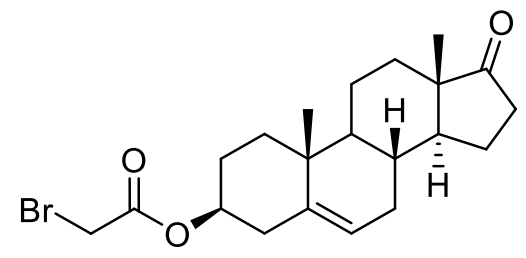

48

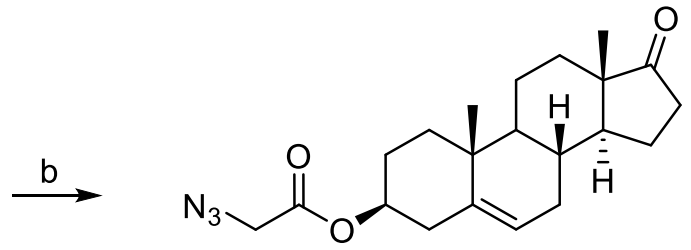

49

Reagents : a- bromoacetyl bromide, $\mathrm{NaHCO}_{3}, \mathrm{DCM} / \mathrm{H}_{2} \mathrm{O}(1 / 1)$, r.t.; b- $\mathrm{NaN}_{3}$, DMSO, r.t., $-50^{\circ} \mathrm{C}$.

Scheme 6. Synthesis of the steroidal azide 49.

The steroidal azide $\mathbf{4 9}$ was used directly for the next step after a simple aqueous work-up procedure. In the first step, a two-phase solvent system $\left(\mathrm{DCM} / \mathrm{H}_{2} \mathrm{O}\right)$ was used; the base $\mathrm{NaHCO}_{3}$ in the aqueous phase neutralized the generated $\mathrm{HBr}$, while the starting materials and the product were in the organic phase. Besides, this condition avoided unwanted side reactions of bromide 48 with $\mathrm{H}_{2} \mathrm{O}$.

The synthesis of alkyne building blocks is shown in Scheme 7. Treatment of 4-hydroxy acetophenone and 4hydroxybenzaldehyde with propargyl bromide in the presence of $\mathrm{K}_{2} \mathrm{CO}_{3}$ gave compounds $\mathbf{5 0}$ and $\mathbf{5 1}$, respectively, which then underwent the $\mathrm{KF} / \mathrm{Al}_{2} \mathrm{O}_{3}$-catalyzed Claisen-Schmidt condensations with aromatic aldehydes and acetophenones, affording substituted chalcones 52a-e and 53a-b.<smiles>C#CCOc1ccc(C(C)=O)cc1</smiles>

50

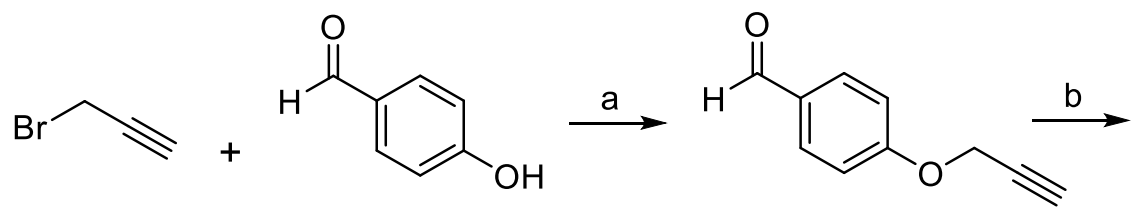

51<smiles>C#CCOc1ccc(C(=O)/C=C/c2cc[R1]cc2)cc1</smiles>

52a-e<smiles>C#CCOc1ccc(/C=C/C(=O)c2cc#[R]cc2)cc1</smiles>

53a-b

Reagents : a- $\mathrm{K}_{2} \mathrm{CO}_{3}$, DMF, r.t.; b- $\mathrm{Al}_{2} \mathrm{O}_{3} / \mathrm{KF}$, EtOH, $50{ }^{\circ} \mathrm{C}$.

Scheme 7. Synthesis of alkyne building blocks 52 and 53. 
With the azide and alkyne building blocks in hand, the steroidal chalcones $\mathbf{5 4}$ and $\mathbf{5 5}$ were efficiently synthesized through the standard CuAAC reactions in moderate to good yields (Scheme 8).

These compounds showed moderate but remarkably decreased inhibitory activity against SH-SY5Y cells with IC50 values more than 36.64 ? $\mathrm{M}$. They exerted weak or no activity toward other cancer cell lines regardless of their substituent patterns and the nature of substituents.<smiles>[R]c1ccc(C(=O)/C=C/c2ccc(OCc3cn(CC(=O)O[C@H]4CC[C@@]5(C)CC4=CC[C@@H]4[C@@H]6CCC(=O)[C@@]6(C)CC[C@H]45)nn3)cc2)cc1</smiles>

\section{4a-b a $R^{1}=H$}

b $R^{1}=F$

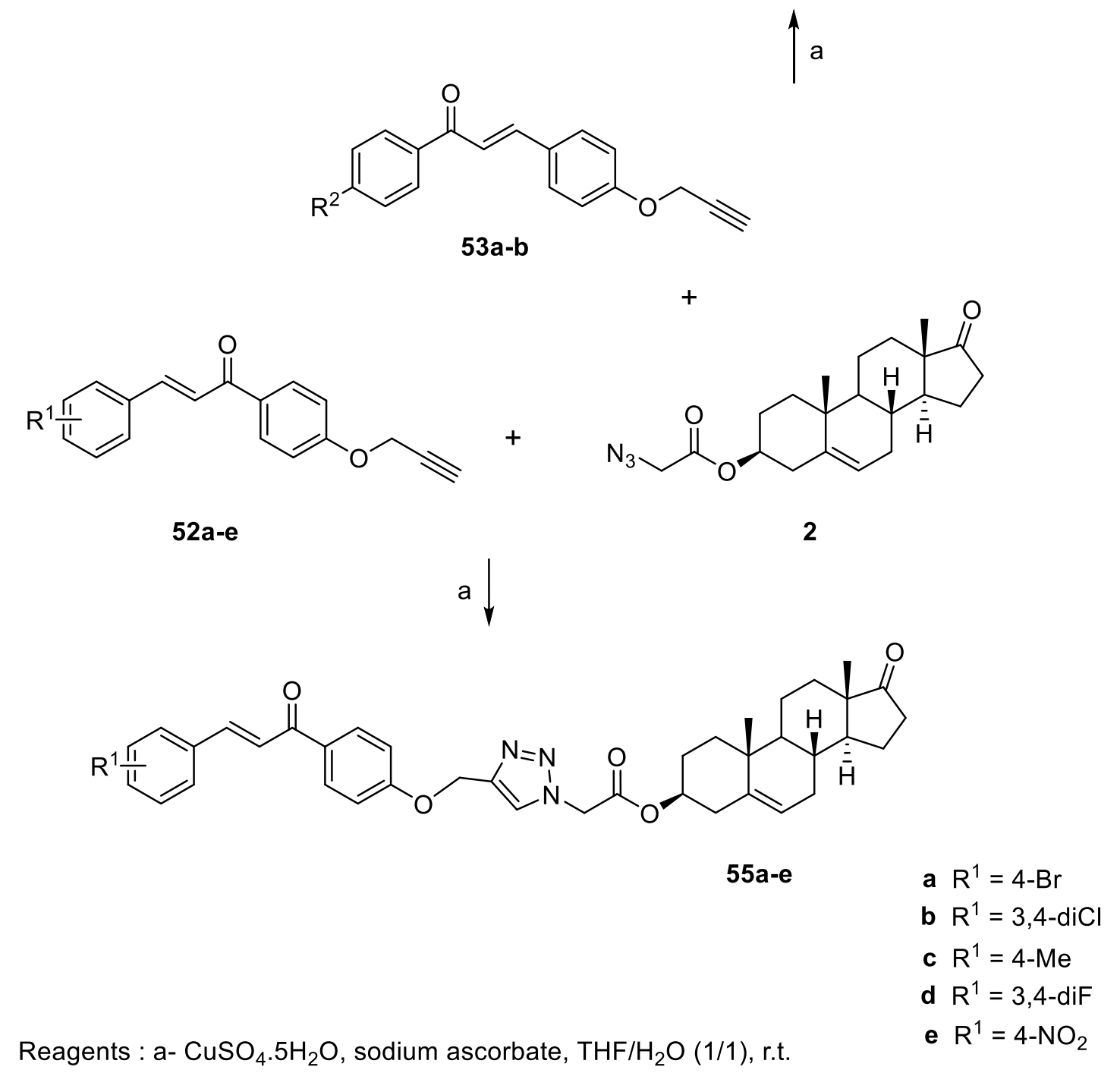

\section{a}

Scheme 8. Synthesis of steroidal chalcones 54 and 55.

In 2020, Xiang et al. ${ }^{29}$ reported the synthesis of a series of novel steroidal-chalcone derivates based on the molecular hybridization strategy. 
The starting material was inexpensive pregnenolone acetate which was reduced by $\mathrm{H}_{2}$ to obtain compound 57. The intermediate $\mathbf{5 8}$ was acquired via a hydrolysis reaction. Subsequently, compound $\mathbf{5 8}$ was oxidized to yield the progesterone 59, whose acetyl group was then oxidized to generate the key intermediate 60 . The compound $\mathbf{6 0}$ reacted with $N$-Boc-ethylenediamine to afford $\mathbf{6 1}$. The compound $\mathbf{6 1}$ was first deprotected and then reacted with various carboxylic acids to offer the final productions 62a-i (Scheme 9). The synthesis of target compounds $\mathbf{6 4}$ began from the intermediate $\mathbf{6 1}$ that was dehydrogenized by DDQ to form the intermediate 63 . Then, the final compounds $64 a-i$ were obtained through deprotection and condensation reaction.<smiles>CC(=O)O[C@H]1CC[C@@]2(C)C(=CCC3C4CC=C(C(C)=O)[C@@]4(C)CCC32)C[C@H](OC(C)=O)C1</smiles>

56<smiles>CC(=O)C1CCC2C3CC=C4C[C@@H](O)CC[C@]4(C)C3CC[C@]12C</smiles>

58<smiles>CC(=O)C1CCC2C3CCC4=CC(=O)CC[C@]4(C)C3CC[C@]12C</smiles>

59<smiles>[R]c1cc(/C=C/C(=O)NCCNC(=O)[C@@H]2CCC3C4CCC5=CC(=O)CC[C@]5(C)[C@H]4CC[C@]32C)c([R16])c([R2])c1[R]</smiles><smiles>[R]c1cc(/C=C/C(=O)NCCNC(=O)[C@H]2CC[C@H]3[C@@H]4CCC5=CC(=O)C=C[C@]5(C)[C@H]4CC[C@@]23C)c([R])c([R])c1[R]</smiles>

63

$64 a-i$

$\mathrm{R}_{1}=\mathrm{H}$ or OMe; $\mathrm{R}_{2}=\mathrm{H}, \mathrm{OMe}$ or $\mathrm{NO}_{2} ; \mathrm{R}_{3}=\mathrm{H}, \mathrm{OMe}, \mathrm{Cl}, \mathrm{CF}_{3}$ or $\mathrm{NO}_{2} ; \mathrm{R}_{4}=\mathrm{H}$ or OMe.

Reagents : a- $\mathrm{Pd} / \mathrm{C}, \mathrm{H}_{2}, 30^{\circ} \mathrm{C}$, r.t., 6 h; b- $\mathrm{NaOH}, \mathrm{CH}_{3} \mathrm{OH}, 1,4$-dioxane, r.t., 30 min; c- cyclohexanone, aluminium isopropoxide, toluene, reflux, $7 \mathrm{~h}$; $\mathrm{d}$ - $\mathrm{NaOH}, \mathrm{Br}_{2}, 1,4$-dioxane, $0{ }^{\circ} \mathrm{C}$, $1.5 \mathrm{~h}$; e- HATu, DIPEA, DMF, r.t., overnight; f- 1) $\mathrm{CF}_{3} \mathrm{COOH}, \mathrm{CH}_{2} \mathrm{Cl}_{2}, 0^{\circ} \mathrm{C}, 30 \mathrm{~min}$, 2) HATu, DIPEA, DMF, r.t., overnight; g- DDQ,

TBDMSCl, 1,4-dioxane, 2h; h- 1) $\left.\mathrm{CF}_{3} \mathrm{COOH}, \mathrm{CH}_{2} \mathrm{Cl}_{2}, 0{ }^{\circ} \mathrm{C}, 30 \mathrm{~min}, 2\right) \mathrm{HATu}$, DIPEA, DMF, r.t., overnight.

Scheme 9. Synthesis of steroidal chalcones 62 and 64. 
A preliminary biological activity evaluation was carried out. The antiproliferative results showed that most compounds exerted weak activity against human colon cancer cells HT-29 and lung cancer cells A549. In contrast, most compounds showed excellent growth inhibitory activity against human TNBC cells MDA-MB-231. Among these compounds, compounds $62 \mathrm{c}$ (with $\mathrm{R}_{1}=\mathrm{OMe}$ and $\mathrm{R}_{2}=\mathrm{R}_{3}=\mathrm{R}_{4}=\mathrm{H}$ ) demonstrated the most potent activities with the IC50 values of $0.42 \mu \mathrm{M}$. Moreover, compound $62 \mathrm{c}$ could accumulate the ROS levels in MDAMB-231 cells and induced cell apoptosis. Western Blot analysis documented that compound 62c could downregulate anti-apoptotic $\mathrm{Bcl}-2$ but up-regulate pro-apoptotic Bax expression. Additionally, compound 62c could also activate the caspase-3 signaling pathway, which accelerated the apoptosis of MDA-MB-231 cells.

In 2021, Rashid et al. ${ }^{30}$ described the synthesis of chalcone derivatives of pregnenolone via base-catalyzed Claisen-Schmidt condensation reaction.

The synthesis of compounds 66a-c was carried out in ethanolic potassium hydroxide by treating Pregnenolone 19 with a series of both the substituted and non-substituted aromatic aldehydes 65a-c. The synthetic process is outlined in Scheme 10.

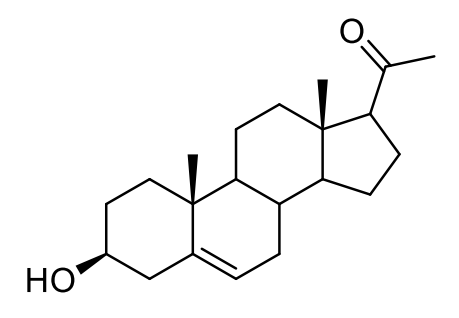

19<smiles>[R]c1ccc(C=O)cc1</smiles>

65a-c<smiles>[R]c1ccc(/C=C/C(=O)[C@@H]2CC[C@H]3[C@@H]4CC=C5C[C@@H](O)CC[C@]5(C)[C@H]4CC[C@@]32C)cc1</smiles>

66a-c

$$
\mathrm{R}=\mathrm{H}, \mathrm{Cl}, \mathrm{CH}_{3}
$$

Reagents : a- $\mathrm{KOH} / \mathrm{MeOH}$, r.t., $18-20 \mathrm{~h}$.

Scheme 10. Synthesis of chalcone derivatives of pregnenolone.

Subsequently, the syntheses of 3,4-dihydropyrimidin-2(1H)-one 70a-c and 3,4-dihydropyrimidin-2(1H) thione 71a-c and 2-amino-3,4-dihydropyrimidine 72a-c derivatives of pregnenolone-chalcones were carried out in ethanolic potassium hydroxide by treating chalcone derivatives of pregnenolone 66a-c with urea 67/thiourea 68/guanidine $\mathrm{HCl}$ 69. The process of synthesis is outlined in Scheme 11. 
<smiles>C[C@]12CC[C@@H](O)CC1=CCC1C2CC[C@@]2(C)C(C(=O)/C=C/c3ccc(I)cc3)CCC12</smiles><smiles>[X]C(N)=O</smiles>

$66 a-c$

$$
\mathrm{R}=\mathrm{H}, \mathrm{Cl}, \mathrm{CH}_{3}
$$

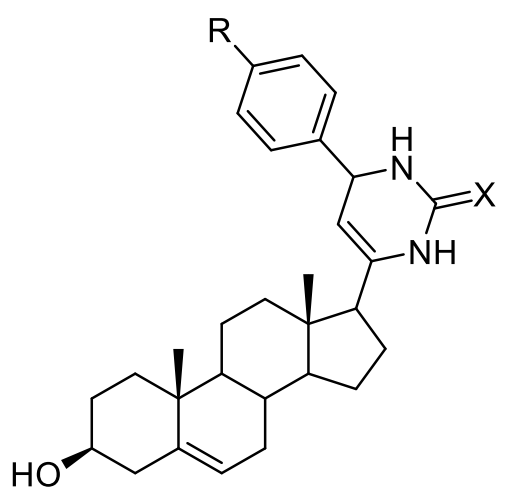

70a-c $X=0$

71a-c $X=S$

72a-c $\quad X=N H$

Reagents : a- $\mathrm{KOH} / \mathrm{EtOH}$, reflux, 8-10 h.

Scheme 11. syntheses of 3,4-dihydropyrimidin-2(1H)-one 70a-c and 3,4-dihydropyrimidin-2(1H) -thione 71a-c and 2-amino-3,4-dihydropyrimidine $72 \mathrm{a}-\mathrm{c}$ derivatives of pregnenolone-chalcones.

Cell viability test of synthesized steroidal chalcones and their pyrimidine and thiopyrimidine derivatives against human breast (MCF-7), human lung (A549), and human prostate (PC-3) cancer cell lines was done using MTT ((4,5-dimethylthiazol-2-yl)-2,5-diphenyltetrazolium bromide), assay. Compounds were further evaluated for their inhibition potential against recombinant human DHFR (rhDHFR). All compounds showed activity from the low micromolar to the submicromolar range. Compound $\mathbf{7 2 b}$ with an IC50 value of $180 \mathrm{nM}$ emerged as the most potent compound against rhDHFR. Interaction of the newly synthesized pregnenolone derivatives with hDHFR and estrogen receptor alpha (ER $\alpha$ ) was also explored via docking simulations. The overall results of hDHFR inhibition have shown that these analogs can be further optimized and developed as potent anticancer agents.

\section{Conclusions}

The present review offers up-to-date literature on the syntheses of steroidal chalcones and derivatives reported during the last years. An almost infinite quantity of new molecules with various structures can be obtained by coupling two or more natural compounds. The objective of such syntheses is to combine the pharmacological properties of two or more biologically active molecules to increase or modulate these activities to obtain derivatives exhibiting new properties. In general, it has been observed that the unsaturated chalcone moiety in the synthesized compounds is at the origin of the activity of steroidal chalcones. Generally speaking, it is observed that the steroids and the resulting derivatives continue to be of interest to researchers, given the biological potential inherent in this family of molecules. 


\section{Acknowledgements}

The CNRS and the Ministère de l'Enseignement Supérieur et de la Recherche have financially supported this work.

\section{References}

1. Zeelen, J. F. Medicinal chemistry of steroids; Elsevier: Amsterdam, Netherlands, 1990.

2. Trager, L. F. Steroidhormone; Springer: Berlin, 1977.

3. Biellmann, J. F. Chem. Rev. 2003, 103, 2019.

http://doi.org/10.1021/cr020071b

4. Nising, C. F.; Bräse, S. Angew. Chem. Int. Ed. 2008, 47, 9389.

https://doi.org/10.1002/anie.200803720

5. Hanson, J. R. Nat. Prod. Reports 2010, 27, 887.

https://doi.org/10.1039/C001262A

6. Bai, X. G.; Xu, C. L. ; Zhao, S. S.; He, H. W.; Wang, Y. C.; Wang, J. X. Molecules 2014, 19, 17256.

7. Bandgar, B. P.; Gawande, S. S.; Bodade, R. G.; Totre, J. V.; Khobragade, C. N. Bioorg. Med. Chem. 2010,18, 1364.

https://doi.org/10.1016/i.bmc.2009.11.066

8. ElSohly, H. N.; Joshi, A. S.; Nimrod, A. C; Walker, L. A.; Clark, A. M. Planta Med. 2001, 67, 87.

9. Kakati, D.; Sarma, R. K.; Saikia, R.; Barua, N. C.; Sarma, J. C. Steroids 2013, 78, 321.

https://doi.org/10.1016/i.steroids.2012.12.003

10. Bhat, B. A.; Dhar, K. L.; Puri, S. C.; Saxena, A. K.; Shanmugavel, M.; Qazi, G. N. Bioorg. Med. Chem.Lett. 2005, 15, 3177.

https://doi.org/10.1016/j.bmcl.2005.03.121

11. Magyar, A.; Wölfling, J.; Kubas, M.; Cuesta Seijo, J. A.; Sevvana, M.; Herbst-Irmer, R.; Forg'o, P.;

Schneider, G. Steroids 2004, 69, 301.

https://doi.org/10.1016/i.steroids.2004.01.004

12. Mehta, G.; Singh, V. Chem. Soc. Rev. 2002, 31, 324.

https://doi.org/10.1039/B204748A

13. Lone, I. H.; Khan, K. Z.; Fozdar, B. I.; Hussain, F. Steroids 2013, 78, 945.

https://doi.org/10.1016/i.steroids.2013.05.015

14. Hirschmann, R.; Steinberg, N. G.; Buchschacher, P.; Fried, J. H.; Kent, G. J.; Tishler, M.; Steelman, S. L. J.

Am. Chem. Soc. 1963, 85, 120.

https://doi.org/10.1021/ja00884a034

15. Saxena, H. O.; Faridi, U.; Kumar, J. K.; Luqman, S.; Darokar, M. P.; Shanker, K.; Chanotiya, C. S.; Gupta, M.

M.; Negi, A. S. Steroids 2007, 72, 892.

https://doi.org/10.1016/i.steroids.2007.07.012

16. Sisodia, B. S.; Negi, A. S.; Darokar, M. P.; Dwivedi, U. N.; Khanuja, S. P. S. Chem. Biol. Drug. Des. 2012, 79, 610.

https://doi.org/10.1111/j.1747-0285.2012.01323.x

17. Saxena, H. O.; Faridi, U.; Kumar, J. K.; Luqman, S.; Darokar, M. P.; Shanker, K.; Chanotiya, C. S.; Gupta, M. M.; Negi, A. S. Steroids 2007, 72, 892. 
https://doi.org/10.1016/i.steroids.2007.07.012

18. Vilsmeier, A.; Haack, A. Chem. Ber. 1927, 60, 119.

https://doi.org/10.1002/cber.19270600118

19. Lawrence, N. J.; Simon, E.; Armitage, M.; Greedy, B.; Cook, D.; Ducki, S; McGown, A. T. Tetrahedron Lett 2006, 47,1637.

https://doi.org/10.1016/i.tetlet.2005.12.110

20. Kakati, D.; Sarma, R. K.; Saikia, R.; Barua, N. C.; Sarma, J. C. Steroids 2013, 78, 321. https://doi.org/10.1016/i.steroids.2012.12.003

21. Baulieu, E. E.; Robel, P. J. Steroid Biochem. Mol. Biol. 1990, 37, 395. https://doi.org/10.1016/0960-0760(90)90490-C

22. Choudhary, M. I.; Alam, M. S.; Rahman, A. U.; Yousuf S.; Wu Y. C.; Lin, A. S. Steroids 2011, 76, 1554. https://doi.org/10.1016/i.steroids.2011.09.006

23. El Sayed Aly, M. R.; Saad, H. A.; Abdel-Hafez, S. H. Beilstein J. Org. Chem. 2015, 11, 1922. https://doi.org/10.3762/bjoc.11.208

24. El Sayed Aly, M. R.; Saad, H. A.; Abdel-Hafez, S. H. Bioorganic \& Medicinal Chemistry Letters 25 (2015) 2824-2830. http://dx.doi.org/10.1016/j.bmcl.2015.04.096

25. Appel, R. Angew. Chem., Int. Ed. Engl. 1975, 14, 801-811. https://doi.org/10.1002/anie.197508011

26. Rostovtsev, V. V.; Green, L. G.; Fokin, V. V.; Sharpless, K. B. Angew. Chem., Int. Ed. 2002, 41, 2596. http://dx.doi.org/10.1002/1521-3773(20020715)41:14

27. Yu, B.; Qi, P. P.; Shi, X. J.; Huang, R.; Guo, H.; Zheng, Y. C.; Yu, D. Q.; Liu, H. M. Eur. J. Med. Chem. 2016, 117, 241. https://doi.org/10.1016/i.ejmech.2016.04.024

28. Stacy, D. M.; Le Quement, S. T. Hansen, C. L.; Clausen, J. W.; Tolker-Nielsen, T.; Brummond, J. W.; Givskov, M.; Nielsen, T.E.; Blackwell, H. E. Org. Biomol. Chem. 2013, 11, 938. https://doi.org/10.1039/C2OB27155A

29. Hou, Q.; Lin, X.; Lu, X.; Bai, C.; Wei, H.; Luo, G.; Xiang, H. Bioorg. Med. Chem. 2020, 28, 115763. https://doi.org/10.1016/i.bmc.2020.115763

30. Tufail, M. B.; Javed, M. A.; Ikram, M.; Mahnashi, M. H.; Alyami, B. A.; Alqahtani, Y. S.; Sadiq, A.; Rashid, U. Steroids 2021, 168, 108801. https://doi.org/10.1016/i.steroids.2021.108801 


\section{Authors' Biographies}

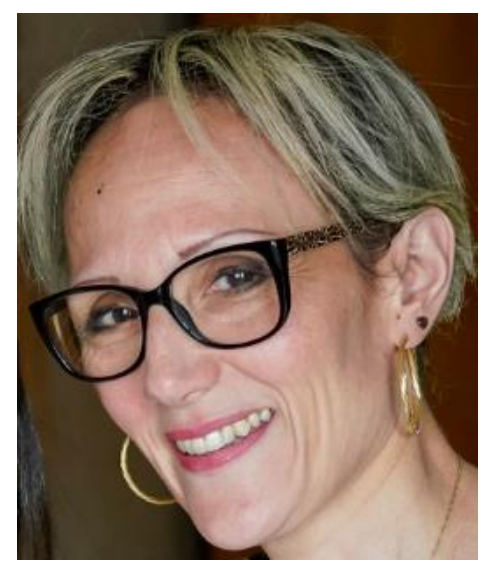

Malika Ibrahim-Ouali carried out her Ph.D. under the supervision of Professor Gramain in Clermont-Ferrand (France) in 1996. The work was focused on the synthesis of alkaloids. She was a postdoctoral fellow with Prof. Knochel (Humboldt fellowship) in 1996 in Germany where she got her first training in organometallic chemistry. In 1997, she joined Professor H. P Husson's group at the ICSN (Paris) as a postdoctoral researcher. Since 1998, she is currently an Associate Professor at Aix-Marseille University and her field of interest remains the total synthesis of natural compounds.

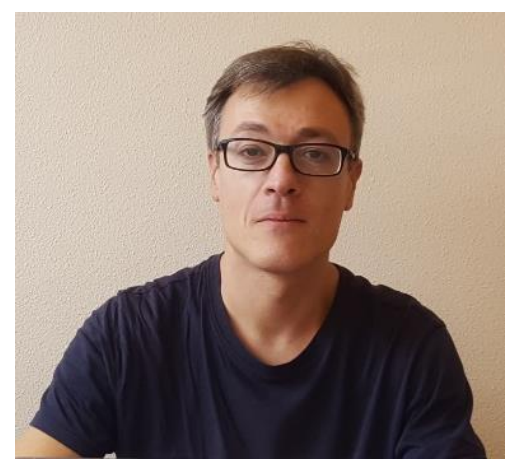

Frédéric Dumur received his Ph.D. in chemistry in 2002 from the University of Angers (France) under the supervision of Professor Pietrick Hudhomme. After Post-Doctoral studies at the University of Groningen (The Netherlands), Reims Champagne-Ardennes (France) and Versailles Saint-Quentin-en-Yvelines (France), he joined the Faculty of Sciences at Aix-Marseille University in 2008, where he is currently working as an Associate Professor. His research interests include the synthesis of phosphorescent dopants for OLEDs and photoinitiators of polymerization. He co-authored about 300 publications and 5 book chapters. 